\title{
Revisiting the estimation of cutting power with different energetic methods while sawing soft and hard woods on the circular sawing machine: a Central European case
}

\author{
Kazimierz A. Orlowski ${ }^{1}$ - Tomasz Ochrymiuk ${ }^{2}$ (D) Ludka Hlaskova ${ }^{3}$. \\ Daniel Chuchala ${ }^{1}$ (D) Zdenek Kopecky ${ }^{3}$
}

Received: 12 March 2019 / Published online: 15 February 2020

(c) The Author(s) 2020

\begin{abstract}
In the classical approaches, used in Central Europe in practice, cutting forces and cutting power in sawing processes of timber are commonly computed by means of the specific cutting resistance $k_{c}$. It needs to be highlighted that accessible sources in handbooks and the scientific literature do not provide any data about wood provenance, nor about cutting conditions, in which cutting resistance has been empirically determined. In the analyses of sawing processes, the use of a model with elements of fracture mechanics involved is an alternative way. In this work, predictions of the newly developed model (FRAC_MOD) for the circular sawing machine are presented. Thanks to this modern approach, it was possible to reveal the usefulness of the FRAC_MOD, using experimental results data on fracture toughness and shear yield stresses of both Polish pine (Pinus sylvestris L.) and Czech beech wood (Fagus sylvatica L.). The achieved results were compared to the forecasted values obtained with classical models (CLAS_PL and CLAS_CZ), which are commonly applied in Central European sawmills. The carried out analyses allowed us to discover undesired effects in the form of underestimation of cutting power when applying the CLAS_PL and CLAS_CZ models. For that reason, the FRAC_MOD cutting model could be suggested for the prediction of energetic effects in cases of dynamical analyses and even unsteady cases.
\end{abstract}

\section{List of symbols}

$\begin{array}{ll}A, B, C & \text { Values from nomographs (CLAS_CZ) } \\ A_{\mathrm{Dav}} & \text { Average cross-sectional area of uncut chip } \\ D & \text { Diameter of the circular saw blade } \\ F_{c} & \text { Cutting force } \\ H_{p} & \text { Workpiece high } \\ P_{\mathrm{EM}} & \text { Power of installed electric motors }\end{array}$

Kazimierz A. Orlowski

kazimierz.orlowski@pg.edu.pl

Extended author information available on the last page of the article 


\begin{tabular}{|c|c|}
\hline$P_{\mathrm{ac}}$ & Power for chips acceleration \\
\hline$P_{c}$ & Cutting power \\
\hline$P_{c_{-} \mathrm{CF}}$ & Cutting power of chip formation \\
\hline$P_{c_{-} \text {Tot }}^{-}$ & Total cutting power \\
\hline$Q_{\text {shear }}$ & Friction correction \\
\hline$R$ & Fracture toughness \\
\hline$R_{\perp}, R_{\|}$ & Fracture toughness for basic directions of cutting \\
\hline$R_{\| \perp}$ & Fracture toughness for intermediate direction of cutting \\
\hline$S_{t}$ & Overall set (kerf) \\
\hline$Z$ & Parameter which makes shear angle material dependent \\
\hline$a$ & $\begin{array}{l}\text { Position of the workpiece relative to rotation axis of circular saw } \\
\text { blade }\end{array}$ \\
\hline$a_{d}$ & Coefficient taking into account wear of blade (CLAS_CZ) \\
\hline$c_{\mathrm{ws}}$ & Coefficient taking into account a type of wood (CLAS_PL) \\
\hline $\mathrm{c}_{\mathrm{MC}}$ & $\begin{array}{l}\text { Coefficient taking into account a moisture content of wood } \\
\text { (CLAS_PL) }\end{array}$ \\
\hline$c_{\mathrm{vc}}$ & $\begin{array}{l}\text { Coefficient taking into account the value of cutting speed } \\
\text { (CLAS_PL) }\end{array}$ \\
\hline$c_{\delta}$ & Coefficient taking into account cutting angle (CLAS_PL) \\
\hline$c_{d}$ & Coefficient taking into account wear of blade (CLAS_PL) \\
\hline$c_{\mathrm{wT}}$ & Coefficient taking into account temperature of wood (CLAS_PL) \\
\hline$c_{h}$ & Coefficient taking into account uncut chip thickness (CLAS_PL) \\
\hline$c_{\mu}$ & $\begin{array}{l}\text { Coefficient taking into account friction between the cut wood } \\
\text { and saw blade (CLAS_PL) }\end{array}$ \\
\hline$c_{\mathrm{CE}}$ & $\begin{array}{l}\text { Coefficient taking into account shape and dimensions of cutting } \\
\text { blade (CLAS_PL) }\end{array}$ \\
\hline$c_{\mathrm{p}}$ & $\begin{array}{l}\text { Coefficient taking into account pressure exerted on the work- } \\
\text { piece before a blade (CLAS_PL) }\end{array}$ \\
\hline$d$ & Hole diameter of the circular saw blade \\
\hline$h$ & Uncut chip thickness \\
\hline$h_{\mathrm{av}}$ & Average uncut chip thickness \\
\hline$h_{j}$ & Instantaneous uncut chip thickness \\
\hline$k_{c}$ & Specific cutting resistance \\
\hline$k_{\mathrm{ws}}$ & Coefficient taking into account type of wood (CLAS_CZ) \\
\hline$k_{c<01}^{1}$ & Basic specific cutting resistance (CLAS_CZ) \\
\hline$k_{\varphi}^{c=0}$ & Basic specific cutting resistance for pine \\
\hline$k_{\|}, k_{\#}, k_{\perp}$ & Basic specific cutting resistance for basic directions of cutting \\
\hline$k_{\| \#,}, k_{\| \perp}, k_{\# \perp}, k_{\| \# \perp}$ & $\begin{array}{l}\text { Basic specific cutting resistance for intermediate directions of } \\
\text { cutting }\end{array}$ \\
\hline$\dot{m}$ & $\begin{array}{l}\text { Mass of wood (chips) evacuated in a certain period of time at a } \\
\text { certain cutting tool velocity }\end{array}$ \\
\hline$p$ & $\begin{array}{l}\text { Parameter expressing the artificial effect of the cutting force on } \\
\text { the flank face of the tool }\end{array}$ \\
\hline$s$ & Thickness of circular saw blade \\
\hline$v_{c}$ & Cutting speed \\
\hline$v_{\mathrm{f}}$ & Feed speed \\
\hline
\end{tabular}




$\begin{array}{ll}z & \text { Number of teeth } \\ z_{\mathrm{a}} & \text { Number of teeth being in contact with the kerf (average) } \\ \Phi_{c} & \text { Shear angle which defines the orientation of the shear plane with } \\ \Phi_{\mathrm{G}-\mathrm{edge}} & \text { respect to cut surface } \\ \Phi_{\mathrm{G}-\mathrm{h}} & \text { Directional angle of a cutting edge } \\ \Phi_{\mathrm{G}-\mathrm{vc}} & \text { Directional angle of a chip thickness } \\ \alpha_{f} & \text { Directional angle of a cutting speed } \\ \alpha_{p 1}^{\prime}, \alpha_{p 2}^{\prime} & \text { Side clearance angle } \\ \beta_{f} & \text { Back clearance angle } \\ \beta_{\mu} & \text { Blade angle } \\ \gamma & \text { Friction angle which is given by tan }{ }^{-1} \mu=\beta_{\mu} \\ \gamma_{f} & \text { Shear strain along the shear plane } \\ \delta_{f} & \text { Side rake angle } \\ \kappa_{r} & \text { Cutting angle } \\ \kappa_{r 1}^{\prime}, \kappa_{r 2}^{\prime} & \text { Cutting edge angle } \\ \lambda_{s} & \text { Minor tool cutting edge angle } \\ \mu & \text { Cutting edge inclination angle } \\ \xi & \text { Friction coefficient } \\ \rho & \text { Coefficient taking into account a friction between the workpiece } \\ \tau_{\gamma} & \text { and the blade (CLAS_CZ) } \\ \tau_{\gamma \| l}, \tau_{\gamma \perp} & \text { Density of sawn wood } \\ \tau_{\gamma \| \perp} & \text { Shear yield stress } \\ \varphi_{\mathrm{en}} & \text { Shear yield stress for basic directions of cutting } \\ \varphi_{\mathrm{ex}} & \text { Shear yield stress for intermediate direction of cutting } \\ \varphi_{j} & \text { Angle entrance of teeth in cut material } \\ \varphi_{\mathrm{P}} & \text { Angle exit of teeth from cut material } \\ & \text { Angular position of the } j \text { th tooth (immersion angle) } \\ & \end{array}$

\section{Introduction}

In the future, manufacturing will require much more powerful strategies for the control of processes in a highly automated manufacturing environment. In general, existing methods for the control of manufacturing operations, mainly based on the experience and craftsmanship of the manufacturing engineers/machinists, are becoming obsolete and must be replaced by science-/knowledge-based methods (Grzesik 2017). As costs for energy and raw material are rising, reduction in the saw kerf (Wasielewski et al. 2012; Orlowski and Walichnowski 2013) as well as improvement in the surface quality is becoming increasingly important (Krenke et al. 2017a, b). Hence, proper optimization of the cutting processes calls for the appropriate approach for estimation of cutting forces, since it could help in a better understanding of the interaction of the tool and raw material.

Even though band saws have a narrower kerf than circular saws, the latter are the most common type of tool in wood machining (Kvietková et al. 2015; Nasir et al. 2018). Nasir and Cool (2018), in their recent comprehensive review on wood 
sawing, summarized findings on the impact of cutting factors on tool wear, surface quality and power consumption. Thus, it stands to reason that in the latter paper a discussion on cutting forces examination and estimation is rather limited. On the other hand, Krenke et al. (2017a, b) stated that due to missing model validation, some statistical models such as by Axelsson et al. (1993) and Porankiewicz et al. (2011) are not applicable to cutting force computation for varying test setups or/and parameters which differ from the specific examination.

Orlowski and Ochrymiuk (2017) showed that estimation of energetic effects using the newly developed cutting model (FRAC_MOD) that includes work of separation in addition to plasticity and friction is capable of predictions not only of average values of cutting power but also its dynamical changes. In this model, changes in uncut chip thicknesses, proper variations in shear yield stress and toughness with tooth orientation in relation to grain orientation have been taken into account. Moreover, this line of attack spreads opportunities to model the cutting process with circular saw blades. It should be emphasized that actual values of shear yield stresses and fracture toughness have been achieved empirically during the cutting tests under sawmill conditions according to the procedure described in the paper by Orlowski et al. (2017). Moreover, determination of the cut material properties in cutting tests is recommended as an alternate and effective way (Atkins 2005, 2018; Hlásková et al. 2019; Sandak et al. 2017; Wang et al. 2015). For example, experimental results of cutting forces (with the use of microtome) were the source for the determination of work of fracture of particleboards (Beer et al. 2005).

In Central Europe, the energetic methods are commonly used for estimation of cutting power, and those approaches are based on the specific cutting energy for pine wood. For other species, empirical correction coefficients are recommended. These approaches were proposed by Beršadskij (1967) and Manžos (1974), and later improved by Orlicz (1988) and Lisičan (1996). It should be emphasized that in the latter mentioned sources, the conditions in which the properties of the wood were quantified and the provenance of these species are not given. The latter and material properties have a significant impact on the energy effects of the cutting process (Chuchala et al. 2014). The aim of this study was to compare the results of the cutting power estimation while cutting on the circular sawing machine, which is used in Polish sawmills, with the commonly used models based on empirical approaches in both Poland (CLAS_PL) and Czech Republic (CLAS_CZ), and the newly developed cutting model (FRAC_MOD). The cutting power computation results were compared for two wood species: pine (Pinus sylvestris L.) and beech (Fagus sylvatica L.), which are commonly used in Central Europe.

\section{Theoretical background}

\section{The specific cutting resistance model (CLAS_PL)}

The widespread approach to determining the cutting power in a cutting process is a model, which is based on the specific cutting resistance $k_{c}$ (Böllinghaus et al. 2009; Grzesik 2018; Manžos 1974; Melo et al. 2016; Nascimento et al. 2017; Naylor and 
Hackney 2013; Orlicz 1988; Pinkowski et al. 2016). According to Orlicz (1988), the cutting power could be determined as:

$$
P_{c}=F_{c} \cdot v_{c}=k_{c} \cdot A_{\mathrm{Dav}} \cdot v_{c}=k_{c} \cdot S_{t} \cdot h_{\mathrm{av}} \cdot v_{c}
$$

where $k_{c}$-specific cutting resistance in $\mathrm{N} \mathrm{mm}^{-2} ; P_{c}$-cutting power in $\mathrm{W} ; F_{c}$-cutting force in N; $A_{\text {Dav }}$-average cross-sectional area of uncut chip in $\mathrm{mm}^{2} ; v_{c}$-cutting speed in $\mathrm{m} \mathrm{s}^{-1} ; S_{t}$-the overall set (kerf) in $\mathrm{mm} ; h_{\mathrm{av}}$ - the average uncut chip thickness in mm (Fig. 1).

This approach is widely used to estimate the cutting power for sawing operations on frame machines, circular sawing machines and band sawing machines in the Polish industry. The model CLAS_PL is based on experimentally determined correction factors that are designed to determine changes in factors affecting the cutting process in relation to the adopted basic conditions as follows:

$$
k_{c}=k_{\varphi} \cdot c_{\mathrm{ws}} \cdot c_{\mathrm{MC}} \cdot c_{\mathrm{vc}} \cdot c_{\delta} \cdot c_{d} \cdot c_{\mathrm{wT}} \cdot c_{h} \cdot c_{\mu} \cdot c_{\mathrm{CE}} \cdot c_{\mathrm{p}}
$$

where $c_{\mathrm{ws}}$ - coefficient taking into account the type of wood, for pine wood $c_{\mathrm{ws}}=1$; $c_{\mathrm{MC}}$-coefficient taking into account the moisture content of wood; $c_{\mathrm{vc}}$-coefficient taking into account the value of cutting speed; $c_{\delta}$-coefficient taking into account cutting angle $\delta_{f}$; angle $\delta_{f}$, is defined as a sum of the clearance angle $\alpha_{f}$ and blade angle $\beta_{f} ; c_{d}$-coefficient taking into account wear of blade; $c_{\mathrm{wT}}$-coefficient taking into account the temperature of wood; $c_{h}$-coefficient taking into account uncut chip thickness; $c_{\mu}$-coefficient taking into account friction between the cut wood and saw blade; $c_{\mathrm{CE}}-$ coefficient taking into account shape and dimensions of cutting blade, $c_{\mathrm{p}}$ - coefficient taking into account pressure exerted on the workpiece before a blade (it could be applied to the production of veneer); and $k_{\varphi}$-the basic specific cutting resistance for pine in $\mathrm{N} \mathrm{mm}^{-2}$. Using these correction coefficients, the model takes into account: geometry of cutting blade, cutting parameters, strength of the

Fig. 1 Sawing kinematics on circular sawing machine: $H_{p}$ workpiece height (depth of cut), $a$ position of the workpiece, $\varphi_{j}$ angular tooth position, $\Phi_{\mathrm{G}-\mathrm{vc}}$ angle between the wood grains and the cutting speed direction, $\varphi_{\text {en }}$ angle of teeth entrance, $\varphi_{\mathrm{ex}}$ exit angle

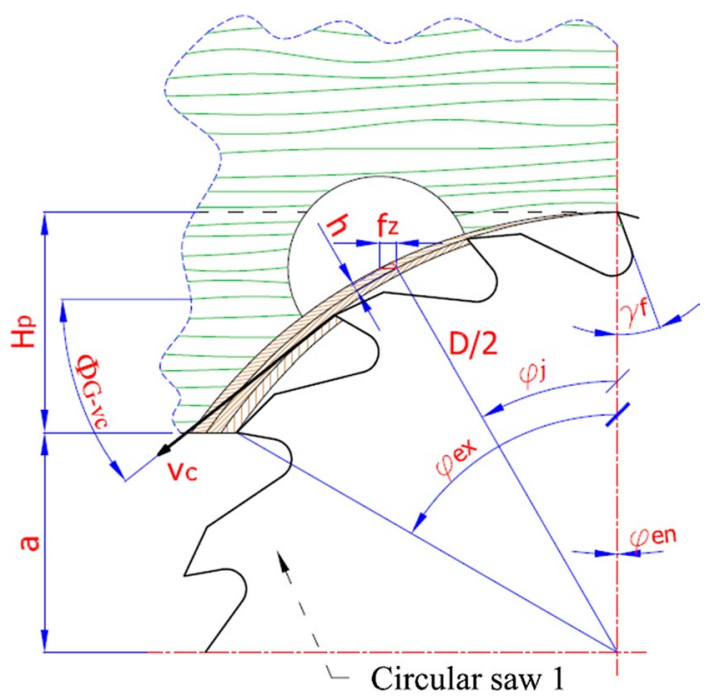


raw material and friction between blade and workpiece. The value of $k_{\varphi}$ is strictly dependent on the relative position of the cutting edge direction and the wood fiber direction (Fig. 2). Those values take into account the basic directions of cutting $k_{\|}$, $k_{\#}, k_{\perp}$ and intermediate directions of cutting $k_{\| \#,}, k_{\| \perp}, k_{\# \perp}, k_{\| \# \perp}$. To determine the value of basic specific cutting resistance in any direction of cutting for the edge, it is necessary to use below equation (Orlicz 1988):

$$
k_{\varphi}=k_{\|} \cdot \cos ^{2} \Phi_{\mathrm{G}-\mathrm{vc}}+k_{\#} \cdot \cos ^{2} \Phi_{\mathrm{G}-\mathrm{edge}}+k_{\perp} \cdot \cos ^{2} \Phi_{\mathrm{G}-\mathrm{h}}
$$

where $\Phi_{\mathrm{G}-\mathrm{vc}}$ - the directional angle of the cutting speed; $\Phi_{\mathrm{G} \text {-edge }}$ - the directional angle of the cutting edge; $\Phi_{\mathrm{G}-\mathrm{h}}$ - the directional angle of the chip thickness (Fig. 2).

When the cutting process takes place in basic conditions, the values of all the correction factors are equal to 1 . Then, the specific cutting resistance $k_{c}$ takes the form of the basic specific cutting resistance $k_{\varphi}$ :

$$
k_{c}=k_{\varphi} \cdot 1=k_{\varphi}
$$

\section{The specific cutting resistance model (CLAS_CZ)}

For theoretical purposes and industrial practice, analytical methods are still applied (Lisican 1996; Manžos 1974; Orlicz 1988; Naylor et al. 2012). The empirical model of power estimation, which is used in Czech Republic, was developed by Beršadskij (1967) and modified by Lisičan (1996). The energy effects can be calculated theoretically using this conventional model (CLAS_CZ), which is based on the specific cutting resistance. In the model, several empirical coefficients are involved, and the model takes into account phenomena of cutting force interactions on the rake face and the flank face of the tool. It should be emphasized that the specific cutting resistance for small $\left(h_{\mathrm{av}} \leq 0.1 \mathrm{~mm}\right)$ and large $\left(h_{\mathrm{av}} \geq 0.1 \mathrm{~mm}\right)$ average uncut chip thickness (Fig. 1) is calculated in a different way. In the CLAS_CZ model, the wear of the cutting edge is calculated as a function of the total actual trajectory of the cutting edge

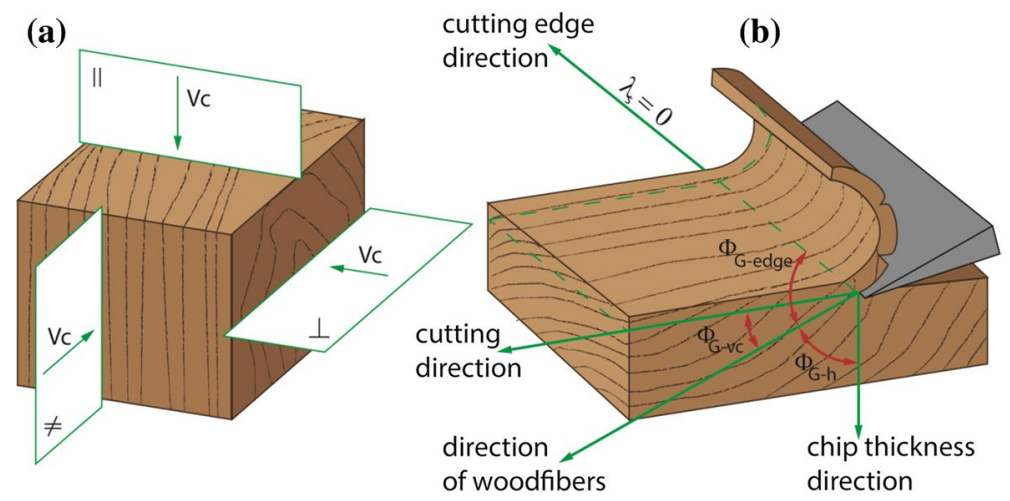

Fig. 2 The main directions of the cutting edge (a) and directional angles (b), which define position of the cutting edge (Orlicz 1988) 
in the sawn raw material. Moreover, it also takes into account the effect of the material of which the edge is made.

The specific cutting resistance $k_{c}$ for average uncut chip thickness $h_{\mathrm{av}} \geq 0.1 \mathrm{~mm}$ is given by:

$$
k_{c}=k_{\geq 0,1}^{1}+\frac{a_{d} \cdot p}{h_{\mathrm{av}}}+\frac{\xi \cdot H_{p}}{S_{t}}
$$

where $k_{c \geq 0,1}^{1}$ - the basic specific cutting resistance for pine in $\mathrm{N} \mathrm{mm}^{-2} ; a_{d}$-coefficient taking into account wear of blade; $p$-parameter expressing the artificial effect of the cutting force on the flank face of the tool in $\mathrm{N} \mathrm{mm}^{-1} ; h_{\mathrm{av}}$ - the average uncut chip thickness in $\mathrm{mm} ; \xi$-coefficient taking into account friction between the workpiece and the blade; $H_{p}$ - height of the workpiece in $\mathrm{mm} ; S_{\mathrm{t}}$ - the overall set (kerf) in $\mathrm{mm}$,

$$
k_{c \geq 0,1}^{1}=\left(A \cdot \delta_{f}+B \cdot v_{c}-C\right) \cdot 10 \cdot k_{\mathrm{ws}}
$$

where $A, B, C$-values from nomographs (for practical purpose calculation, graphs of parameters $A, B, C$ were plotted as a function of mean fiber cutting angle $\varphi_{2}$ in $\mathrm{N} \mathrm{mm}^{-2}, \delta_{f}$-cutting angle, $v_{c}$-cutting speed in $\mathrm{m} \mathrm{s}^{-1}, k_{\mathrm{ws}}$-coefficient taking into account the type of wood, for pine wood $k_{\mathrm{ws}}=1$ ).

Using this CLAS_CZ model, the user can take into account the geometry of teeth, cutting parameters, strength of the raw material, changes in the edge geometry caused by the wear and friction between the tooth and the workpiece. The value of $k_{c \geq 0.1}^{1}$ is strictly dependent on the relative position of the cutting speed direction in relation to the wood fibers.

\section{The newly developed cutting model (FRAC_MOD)}

The newly developed cutting model (FRAC_MOD), which includes plasticity and friction, and where work of separation is not omitted in the model, is capable of forecasting not only average values of cutting power but also its dynamical changes (Orlowski and Ochrymiuk 2017). In the FRAC_MOD, it was assumed that cutting force $F_{c}$, acting in the middle of the cutting edge, is an equilibrium of forces related to the direction of primary motion for a single saw tooth, and the mechanical process of material separation from the sawn workpiece, i.e., chip formation, can be approximately described by the example of an orthogonal process (two-dimensional deformation) (Orlowski et al. 2013, 2014; Orlowski and Ochrymiuk 2013; Hlásková et al. 2015, 2018).

The model originally proposed in a work by Orlowski et al. (2013) can be expressed as:

$$
P_{c}(\varphi)=P_{c_{-} \mathrm{CF}}(\varphi)+P_{c_{-} \mathrm{ac}}=v_{c} S_{t} \sum_{j=1}^{j=z}\left[\frac{\tau_{\gamma \| \perp_{j} j}(\varphi) \cdot \gamma_{j}(\varphi)}{Q_{\text {shear } j j}(\varphi)} h_{j}(\varphi)+\frac{R_{\| \perp j}(\varphi)}{Q_{\text {shear } \_j}(\varphi)}\right]+\dot{m} v_{c}^{2}
$$


According to Atkins (2009) and Orlowski (2010), the first part of Eq. (7) represents works of plasticity in the cutting zone and friction on the rake plane; the second one takes into account the phenomenon that the chips have to be accelerated to the same speed as the cutting tool velocity $v_{c}$.

In the above model (Eq. 7), it was assumed that the cutting edges of teeth are sharp. Moreover, if we assume the cut is straight, and the cut deviation is low, then the effect of lateral forces on the power consumption can be ignored (Mohammadpanah and Hutton 2016).

In the case of circular sawing, the same as in analytical simulations of milling (Altintas 2000; Ammar et al. 2009; Budak 2006), the immediate uncut chip thickness $h_{j}(\varphi)$ at a definite location of the cutting edge (Fig. 1) can be approximated as follows:

$$
h_{j}(\varphi)=f_{z} \sin \varphi_{j}
$$

The angular position of the $j$ th tooth (engagement angle) $\varphi_{j}$ value changes as follows:

$$
\varphi_{j}=\varphi+(j-1) \varphi_{P} \quad j=1, \ldots, z
$$

where $\varphi_{p}$ is defined as $\varphi_{P}=\frac{2 \pi}{z}$.

If $\varphi_{\mathrm{en}} \leq \varphi_{j} \leq \varphi_{\mathrm{ex}}$, then it has a value; otherwise, it is null. An angle of teeth entrance $\varphi_{\mathrm{en}}$ is given by $\varphi_{\mathrm{en}}=\arccos \frac{2\left(H_{p}+a\right)}{D}$ (when the tool tooth gets into the workpiece for machining), and an exit angle $\varphi_{\text {ex }}$ (the tooth of the saw blade gets out of the workpiece) can be described as $\varphi_{\mathrm{ex}}=\arccos \frac{2 a}{D}$.

The algorithm of cutting power of chip formation is presented in Fig. 3. The steps to follow in this approach are:

- at the position of the cutting edge in relation to the grains, for indirect positions of the cutting edge fracture toughness $R_{\| \perp j}(\varphi)$ and the shear yield stress $\tau_{\gamma \| \perp j}(\varphi)$ are calculated. This approach has been implemented for computation of the shear yield stress and fracture toughness as tensor values (Orlowski et al. 2013; Hlásková et al. 2015) according to Orlicz (1988), who applied the plane stress transformation equation for the determination of specific cutting resistance in indirect positions of the cutting speed direction. It ought to be emphasized that the same method is commonly used in general mechanics of materials to transform the stress components from one set of axes to another (Gere 2004).

- Computation of the parameter $Z$, which makes $\Phi_{c}\left(\varphi_{j}\right)$ material dependent, on the contrary to the classical approach by Merchant (Böllinghaus et al. 2009; Markopoulos 2013).

- The shear angle $\Phi_{c}\left(\varphi_{\mathrm{j}}\right)$ is determined numerically from the equation determining least cutting force $F_{c}$ (for indirect tooth position), which has been proposed by Atkins (2003).

- The shear strain along the shear plane $\gamma_{j}\left(\varphi_{j}\right)$ and the friction correction $Q_{\text {shear }_{j} j}\left(\varphi_{j}\right)$ are calculated.

- The cutting power of chip formation for each tooth is computed, and simultaneously, a plot of cutting power versus an angle of rotation is created; 
The diagram of the calculation course in the method FRAC_MOD

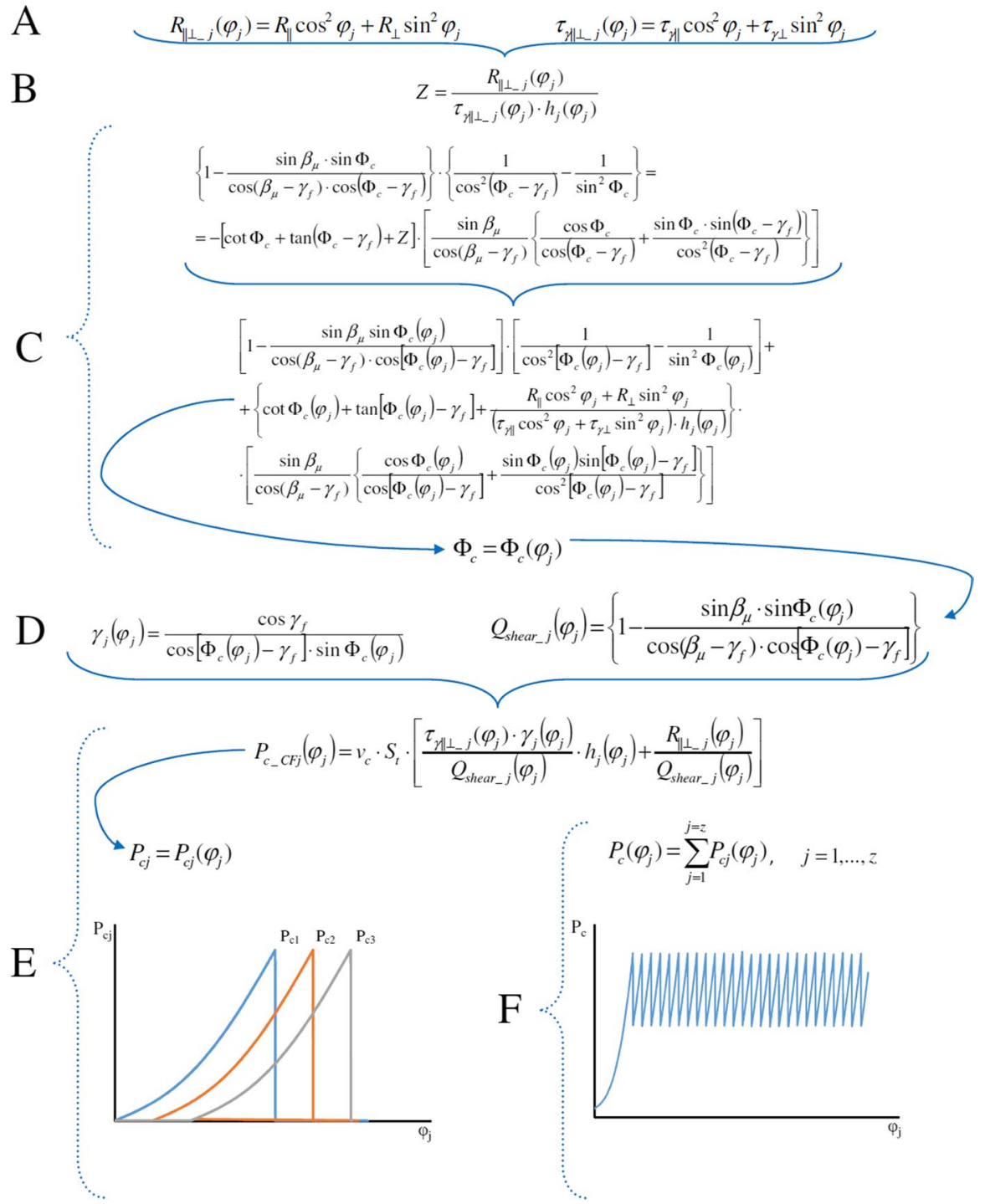

Fig. 3 Algorithm of cutting power of chip formation in FRAC_MOD method

- Eventually, the total cutting power of chip formation $P_{c_{-} \mathrm{CF}}(\varphi)$ is calculated and its relevant graph is generated.

After one full revolution of the tool, i.e., $\varphi$ : $0^{\circ}-360^{\circ}$ maximum, average or rootmean-square (RMS) values of power can be determined (Budak 2006).

The obtained values at the level $F$ ought to be augmented by the chip acceleration power $P_{\mathrm{ac}}$ variation as a function of mass flow and tool velocity (Pantea 1999; 
Orlowski et al. 2013; Atkins 2009). The chip acceleration power $P_{\text {ac }}$ variation in this case is a function of mass flow, and tool velocity is given by:

$$
P_{\mathrm{ac}}=\dot{m} v_{c}^{2}
$$

The mass of wood (chips) evacuated in a certain period of time at a certain cutting speed of the tool $\dot{m}\left(\mathrm{~kg} \mathrm{~s}^{-1}\right)$ can be estimated as follows:

$$
\dot{m}=H_{P} S_{t} v_{\mathrm{f}} \rho
$$

It should be emphasized that in these investigations, it was implied that the chip acceleration power $P_{\mathrm{ac}}$ is not a function of the number of teeth being engaged in the cutting zone.

\section{Materials and methods}

Predictions of cutting power have been made for the case of sawing on the circular sawing machine (HVS R200, f. HewSaw), which is used in Polish sawmills (e.g., Olczyk Sawmill, Krasocin, PL). The simplified sawing system of the circular sawing machine HVS R200 is presented in Fig. 4, and the basic sawing machine data and cutting parameters for which computations were done are shown in Table 1.

It was assumed that one circular saw blade (circular saw 1, Fig. 4) was applied, with technical data as given in Table 1. The tooth geometry in the T-hand-S (toolin-hand system) (Astakhov 2010) is presented in Fig. 5, and the values of angles applied to the circular saw blade are shown in Table 1.

Computations were carried out in each case for one saw blade (Fig. 1) with three different methods:

- the newly developed cutting model that includes work of separation in addition to plasticity and friction FRAC_MOD;

- on the basis of the specific cutting resistance model proposed by Orlicz (1988), which is widely used in Poland CLAS_PL;

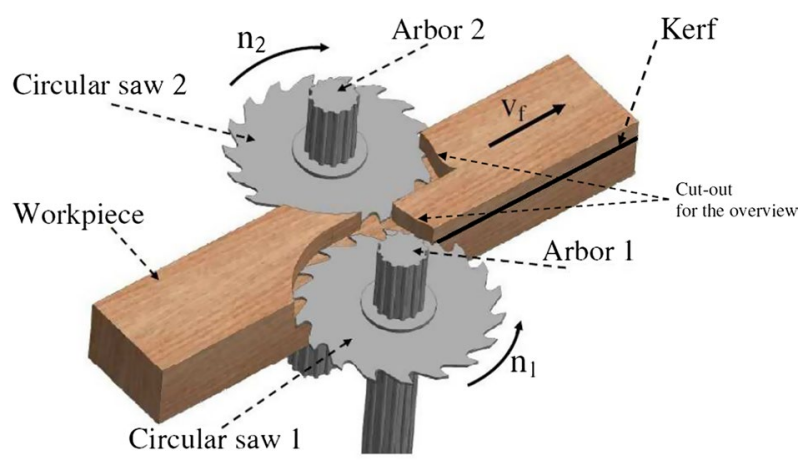

Fig. 4 Simplified sawing system of the circular sawing machine HVS R200 (f. HewSaw) 
Table 1 Tool and machine tool data

\begin{tabular}{|c|c|c|c|}
\hline \multicolumn{2}{|c|}{ Circular sawing machine HVS R200 (f. HewSaw) } & \multicolumn{2}{|l|}{ Tool } \\
\hline Parameter & Value & Parameter & Value \\
\hline$H_{p}(\mathrm{~mm})$ & 80 & $D(\mathrm{~mm})$ & 350 \\
\hline$v_{c}\left(\mathrm{~m} \mathrm{~s}^{-1}\right)$ & 64.14 & $d(\mathrm{~mm})$ & 80 \\
\hline$v_{\mathrm{f}}\left(\mathrm{m} \mathrm{min}^{-1}\right)\left(\mathrm{m} \mathrm{s}^{-1}\right)$ & $70-110-150(1.167-1.833-2.5)$ & $s(\mathrm{~mm})$ & 2.5 \\
\hline$f_{z}(\mathrm{~mm})$ & $0.833-1.309-1.78$ & $S_{\mathrm{t}}(\mathrm{mm})$ & 3.6 \\
\hline$h(\mathrm{~mm})$ & $0.398-0.626-0.854$ & $z(-)$ & 24 \\
\hline \multirow[t]{6}{*}{$P_{\mathrm{EM}}(\mathrm{kW})$} & $2 \times 90$ & $\gamma_{f}\left({ }^{\circ}\right)$ & 22 \\
\hline & & $\alpha_{f}\left({ }^{\circ}\right)$ & 12 \\
\hline & & $\alpha_{p 1}=\alpha_{p 2}\left(^{\circ}\right)$ & 2 \\
\hline & & $\kappa_{r}\left({ }^{\circ}\right)$ & 90 \\
\hline & & $\kappa_{r 1}=\kappa_{r 2}\left({ }^{\circ}\right)$ & 2 \\
\hline & & $\lambda_{s}\left({ }^{\circ}\right)$ & 0 \\
\hline
\end{tabular}

$z$ tooth number, $P_{\mathrm{EM}}$ power of installed electric motors, $\alpha_{f}$ the tool side flank, $\gamma_{f}$ the tool side rake, $\alpha_{p 1}^{\prime}$, $\alpha_{p 2}^{\prime}$ the tool back flank, $\kappa_{r}$ tool cutting edge angle, $\kappa_{r 1}^{\prime}, \kappa_{r 2}^{\prime}$ minor tool cutting edge angle, $\lambda_{\mathrm{s}}$ the cutting edge inclination angle

Fig. 5 The circular saw blade tooth geometry in the tool-inhand system: $\alpha_{f}$ the tool side flank, $\alpha_{p}^{\prime}$ the tool back flank, $\kappa_{r}$ tool cutting edge angle, $\kappa_{r}^{\prime}$ minor tool cutting edge angle, $\gamma_{f}$ the tool side rake, $\lambda_{s}$ the cutting edge inclination angle

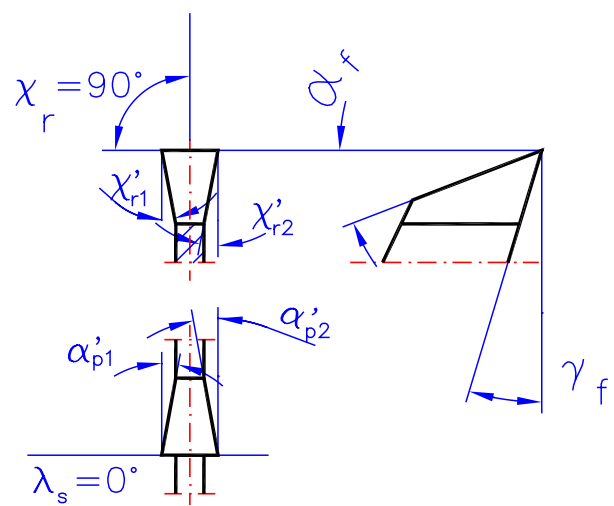

- with the empirical model of power estimation, which is applied to Czech Republic CLAS_CZ.

\section{Data for the model FRAC_MOD}

The raw material was pine wood (P. sylvestris L.) originated from the Forest Inspectorate Lipusz in the Baltic Natural Forest Region (Poland), and beech wood (F. sylvatica L.) originating from the Training Forest Enterprise Masaryk Forest Krrtiny, an organizational part of Mendel University in Brno (Czech Republic).

In Table 2, the raw material data is presented, which was determined experimentally according to the methodology described in the works by: 
Table 2 Raw material data

\begin{tabular}{lll}
\hline & Pine & Beech \\
\hline$R \mid\left(\mathrm{J} \mathrm{m}^{-2}\right)$ & 65 & 114.0 \\
$R_{\perp}\left(\mathrm{J} \mathrm{m}^{-2}\right)$ & 1300 & 3629.1 \\
$\tau_{\gamma \|}(\mathrm{MPa})$ & 5.2 & 11.86 \\
$\tau_{\gamma \perp}(\mathrm{MPa})$ & 20.9 & 49.87 \\
$\rho\left(\mathrm{kg} \mathrm{m}^{-3}\right)$ & 520 & 724 \\
$\mu(-)$ & 0.8 & 0.8 \\
\hline
\end{tabular}

- Orlowski et al. (2017) — for pine wood in the industrial conditions at the Complex Sawmill in Dziemiany (Poland);

- Hlásková et al. (2018)_for beech wood at the laboratory stand, which has the same kinematic system as a circular sawing machine.

The values of friction coefficients $\mu=0.8$ for dry pine wood and beech wood were taken from the works by Beer (2002) and Glass and Zelinka (2010).

\section{Data for the specific cutting resistance model CLAS_PL}

Values of correction coefficients to calculate the value of specific cutting resistance in the model CLAS_PL are shown in Table 3. In this table, values for basic conditions and values for the analyzed conditions of cutting process are shown. Some correction coefficients were selected from the given values in the work by Orlicz (1988), and some values had to be additionally calculated using Eq. (3). These calculated coefficients take into account the axial-perpendicular direction of wood cutting and are marked with star (*) (Table 3). Additionally, coefficients, which take into account an uncut chip thickness $c_{h}$, are described in below equations proposed by Orlicz (1988):

$$
\begin{aligned}
& c_{h \perp}=\left(\frac{0.15}{h_{\mathrm{av}}}\right)^{0.41} \\
& c_{h \|}=\left(\frac{0.15}{h_{\mathrm{av}}}\right)^{0.47}
\end{aligned}
$$

The values obtained with Eqs. (12) and (13) were additionally recalculated with Eq. (3). This procedure allowed us to obtain one value of the coefficient $c_{h}$, which also takes into account the axial-perpendicular direction of wood cutting.

\section{Data for the specific cutting resistance model CLAS_CZ}

Values of correction coefficients and all parameters for calculation of the specific cutting resistance in the CLAS_CZ model are shown in Table 4. In this table, 
Table 3 Values of correction coefficients for the specific cutting resistance for the analyzed conditions of cutting process (Orlicz 1988)

\begin{tabular}{|c|c|c|c|c|}
\hline \multirow{2}{*}{$\begin{array}{l}\text { Correction } \\
\text { coefficient }\end{array}$} & \multicolumn{2}{|l|}{ Pine basic and analyzed conditions } & \multicolumn{2}{|l|}{ Beech analyzed conditions } \\
\hline & Basic data & Value & Analyzed data & Value \\
\hline$c_{\mathrm{ws}}$ & Pine wood (Pinus sylvestris L.) & 1 & Beech wood (Fagus sylvatica L.) & 1.7 \\
\hline$c_{\mathrm{MC}}$ & $\begin{array}{l}\text { Dry wood } \\
M C=10 \div 15 \%\end{array}$ & 1 & $\begin{array}{l}\text { Dry wood } \\
M C=10 \div 15 \%\end{array}$ & 1 \\
\hline$c_{\mathrm{vc}}$ & $\begin{array}{l}\text { Up to } 10 \mathrm{~m} \mathrm{~s}^{-1} \\
64 \mathrm{~m} \mathrm{~s}^{-1}\end{array}$ & $\begin{array}{l}1 \\
1.2\end{array}$ & $64 \mathrm{~m} \mathrm{~s}^{-1}$ & 1.2 \\
\hline$c_{\delta}$ & $\begin{array}{l}\text { If } 60^{\circ} \\
\text { Analyzed case } 68^{\circ}\end{array}$ & $\begin{array}{l}1 \\
1.3^{\mathrm{a}}\end{array}$ & $68^{\circ}$ & $1.3^{\mathrm{a}}$ \\
\hline$c_{d}$ & Sharp blade $\rho_{\mathrm{o}}=4 \div 10 \mu \mathrm{m}$ & 1 & Sharp blade $\rho_{\mathrm{o}}=4 \div 10 \mu \mathrm{m}$ & 1 \\
\hline$c_{\mathrm{wT}}$ & $20^{\circ} \mathrm{C}$ & 1 & $20^{\circ} \mathrm{C}$ & 1 \\
\hline$c_{h}$ & $\begin{array}{l}h=0.15 \mathrm{~mm} \\
h=0.398 \mathrm{~mm}\end{array}$ & $\begin{array}{l}1 \\
0.65^{\mathrm{a}}\end{array}$ & $h=0.398 \mathrm{~mm}$ & $0.65^{\mathrm{a}}$ \\
\hline & $h=0.854 \mathrm{~mm}$ & $0.45^{\mathrm{a}}$ & $h=0.854 \mathrm{~mm}$ & $0.45^{\mathrm{a}}$ \\
\hline$c_{\mu}$ & $\begin{array}{l}\text { Single cutting edge } \\
\text { Circular saw }\end{array}$ & $\begin{array}{l}1 \\
1.05\end{array}$ & Circular saw & 1.05 \\
\hline$c_{\mathrm{CE}}$ & $\begin{array}{l}\text { Single cutting edge } \\
\text { Circular saw }\end{array}$ & $\begin{array}{l}1 \\
1.05\end{array}$ & Circular saw & 1.05 \\
\hline
\end{tabular}

${ }^{\mathrm{a}}$ Values of coefficients which take into account the axial-perpendicular direction of wood cutting

Table 4 Values of correction coefficients for the specific cutting resistance for the analyzed conditions of cutting process used in the CLAS_CZ model

\begin{tabular}{|c|c|c|c|c|}
\hline \multirow{2}{*}{$\begin{array}{l}\text { Correction } \\
\text { coefficient }\end{array}$} & \multicolumn{2}{|l|}{ Pine basic and analyzed conditions } & \multicolumn{2}{|l|}{ Beech analyzed conditions } \\
\hline & Basic data & Value & Analyzed data & Value \\
\hline$A$ & Mean fiber cutting angle $\varphi_{2}=57.12^{\circ}$ & 0.031 & Mean fiber cutting angle $\varphi_{2}=57.12^{\circ}$ & 0.04 \\
\hline$B$ & Mean fiber cutting angle $\varphi_{2}=57.12^{\circ}$ & 0.009 & Mean fiber cutting angle $\varphi_{2}=57.12^{\circ}$ & 0.012 \\
\hline C & $\begin{array}{l}\text { Uncut chip thickness } \mathrm{hm} \geq 0.1 \mathrm{~mm} \\
\text { Mean fiber cutting angle } \varphi_{2}=57.12^{\circ} \\
\text { Circular saw }\end{array}$ & 1.044 & $\begin{array}{l}\text { Uncut chip thickness } \mathrm{hm} \geq 0.1 \mathrm{~mm} \\
\text { Mean fiber cutting angle } \varphi_{2}=57.12^{\circ} \\
\text { Circular saw }\end{array}$ & 1.357 \\
\hline$p$ & $\begin{array}{l}\text { Mean fiber cutting angle } \varphi_{2}=57.12^{\circ} \\
\text { Circular saw }\end{array}$ & 5.111 & $\begin{array}{l}\text { Mean fiber cutting angle } \varphi_{2}=57.12^{\circ} \\
\text { Circular saw }\end{array}$ & 6.644 \\
\hline$k_{\mathrm{ws}}$ & Pine wood (Pinus sylvestris L.) & 1 & Beech wood (Fagus sylvatica L.) & 1.3 \\
\hline$a_{d}$ & Sharp blade $\rho_{\mathrm{o}}=4 \div 10 \mu \mathrm{m}$ & 1 & Sharp blade $\rho_{\mathrm{o}}=4 \div 10 \mu \mathrm{m}$ & 1 \\
\hline$\xi$ & $\begin{array}{l}\text { Circular saw } \\
\text { Swaged teeth }\end{array}$ & 0.59 & $\begin{array}{l}\text { Circular saw } \\
\text { Swaged teeth }\end{array}$ & 0.59 \\
\hline
\end{tabular}

values for the analyzed conditions of cutting process are listed. Correction coefficients and parameters were selected from nomographs and from the recommended values in the work by Lisičan (1996). 


\section{Results and discussion}

Results of predictions of cutting power for chip formation obtained with the use of a newly developed cutting model FRAC_MOD that includes work of separation in addition to plasticity and friction, in the case of sawing of pine from the Forest Inspectorate Lipusz in the Baltic Natural Forest Region (PL) provenance and beech wood originating from the Training Forest Enterprise Masaryk Forest Krrtiny, are shown in Fig. 6. The presented data are for one circular saw blade, at the feed speed $v_{\mathrm{f}}=70 \mathrm{~m} \mathrm{~min}^{-1}$, and $v_{\mathrm{f}}=150 \mathrm{~m} \mathrm{~min}^{-1}$, for one full revolution of the tool (the first one). In this computation, beside uncut chip thickness changes, appropriate changes in shear yield stress and toughness with tooth/grain orientation were taken into account.
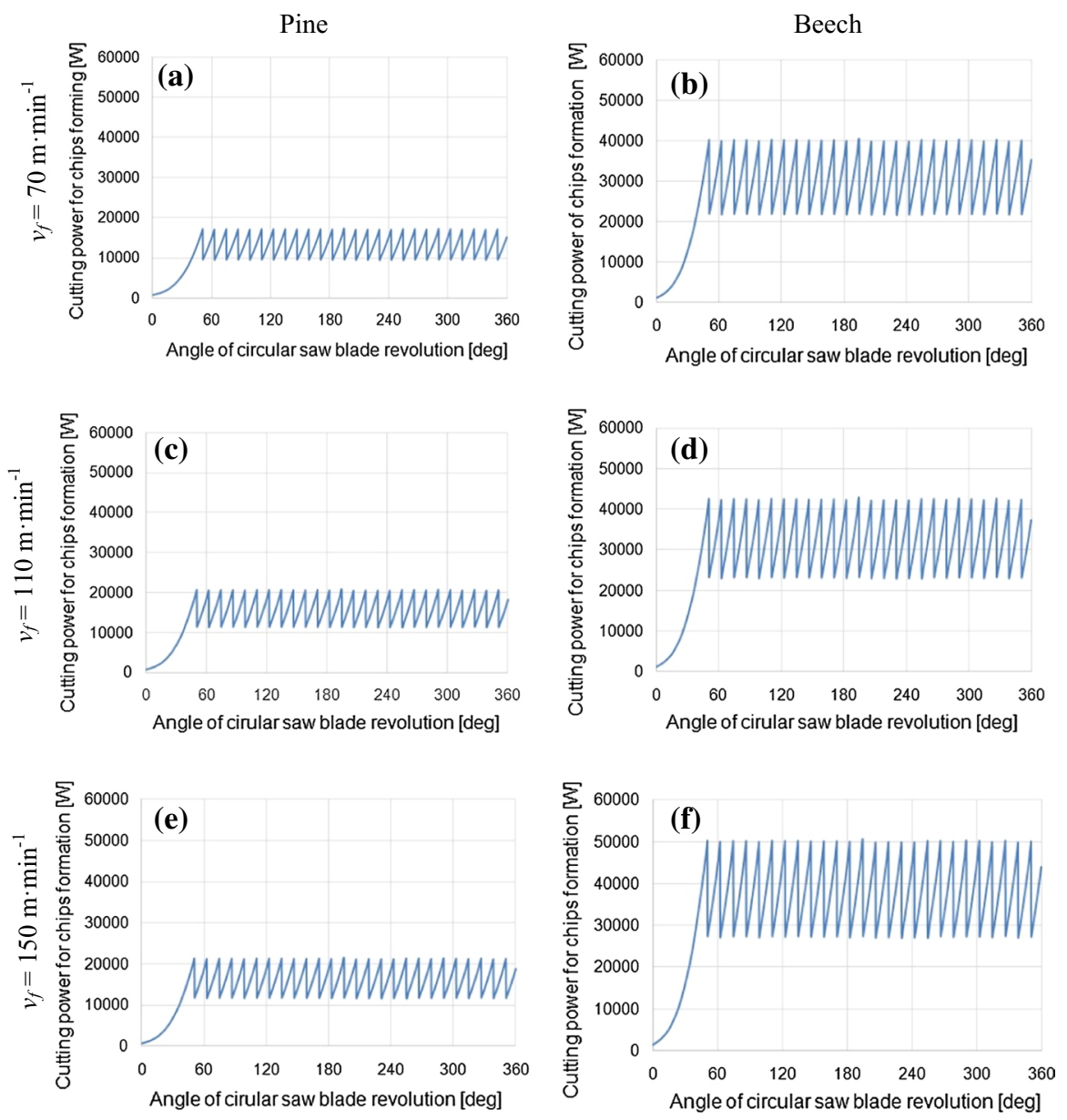

Fig. 6 Cutting power of chips formation as a function of wood species and feed speed $\left(v_{\mathrm{f}}=70 \mathrm{~m} \mathrm{~min}^{-1}\right.$, $v_{\mathrm{f}}=110 \mathrm{~m} \mathrm{~min}^{-1}$ and $v_{\mathrm{f}}=150 \mathrm{~m} \mathrm{~min}^{-1}$ ), where $\mathbf{a}, \mathbf{c}, \mathbf{e}$ pine wood, $\mathbf{b}, \mathbf{d}, \mathbf{f}$ beech wood 

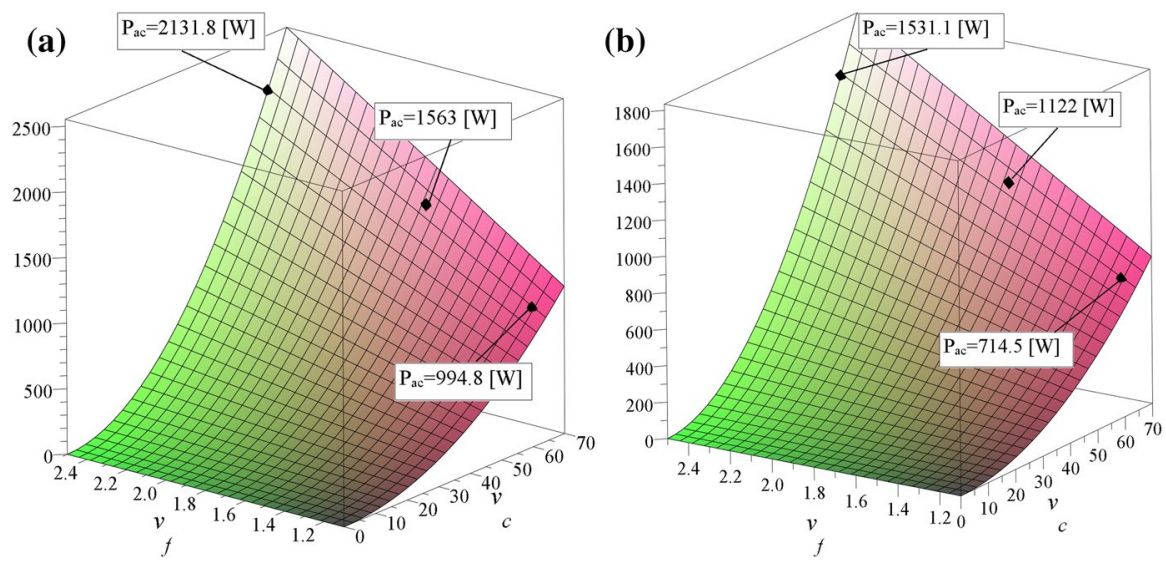

Fig. 7 Predictions of chip acceleration power variation $P_{\mathrm{ac}}$ as a function of cutting speed $v_{c}$ and feed speed $v_{\mathrm{f}}$ for sawing of the beech (a) and pine (b) workpieces of $80 \mathrm{~mm}$ in height with one saw blade on circular sawing machine HSV R200 with marked points of the parameters applied to the forecasting

Table 5 Power for chip formation $P_{c \text { CF }}$ determined in the FRAC_MOD model, the predicted values of chip acceleration power $P_{\mathrm{ac}}$ and total cutting power $P_{c_{-} \text {Tot }}$

\begin{tabular}{|c|c|c|c|c|c|c|}
\hline & \multicolumn{3}{|l|}{ Pine } & \multicolumn{3}{|l|}{ Beech } \\
\hline & $P_{c_{-} \mathrm{CF}}(\mathrm{kW})$ & $P_{\mathrm{ac}}(\mathrm{kW})$ & $P_{c_{-} \text {Tot }}(\mathrm{kW})$ & $P_{c_{-} \mathrm{CF}}(\mathrm{kW})$ & $P_{\mathrm{ac}}(\mathrm{kW})$ & $P_{c_{-} \text {Tot }}(\mathrm{kW})$ \\
\hline$v_{\mathrm{f}}=70\left(\mathrm{~m} \mathrm{~min}^{-1}\right)$ & 11.54 & 0.72 & 12.26 & 21.63 & 0.99 & 22.62 \\
\hline$v_{\mathrm{f}}=110\left(\mathrm{~m} \mathrm{~min}^{-1}\right)$ & 16.01 & 1.12 & 17.13 & 32.76 & 1.56 & 34.32 \\
\hline$v_{\mathrm{f}}=150\left(\mathrm{~m} \mathrm{~min}^{-1}\right)$ & 23.40 & 1.53 & 24.93 & 43.65 & 2.13 & 45.78 \\
\hline
\end{tabular}

Predicted values of chip acceleration power variation $P_{\text {ac }}$ as a function of cutting speed $v_{c}$ and feed speed $v_{\mathrm{f}}$ for sawing of the beech and pine (b) workpieces of $80 \mathrm{~mm}$ in height are shown in Fig. 7.

For a stable condition of cutting power changes in the FRAC_MOD model, the RMS values of the power for chip formation $P_{c_{-} \mathrm{CF}}$ were computed, and the results of computations are presented in Table 5. Beside $P_{c_{-} \mathrm{CF}}$, the predicted values of chip acceleration power need $P_{\text {ac }}$ and total cutting power $P_{c_{-} \text {Tot }}$ are also given in Table 5. The total cutting power $P_{c_{-} \text {Tot }}$ is defined as:

$$
P_{c_{-} \mathrm{Tot}}=P_{c_{-} \mathrm{CF}}+P_{\mathrm{ac}}
$$

Similarly to the described case of sawing with the circular saw of pine wood (Orlowski and Ochrymiuk 2017), it was assumed that the total cutting power determined with the FRAC_MOD model is the reference value, since the predicted values were in agreement with experimental measurement results. The comparison of estimated cutting powers with the model CLAS_PL and the CLAS_CZ model is shown in Fig. 8 and revealed that: 
Pine
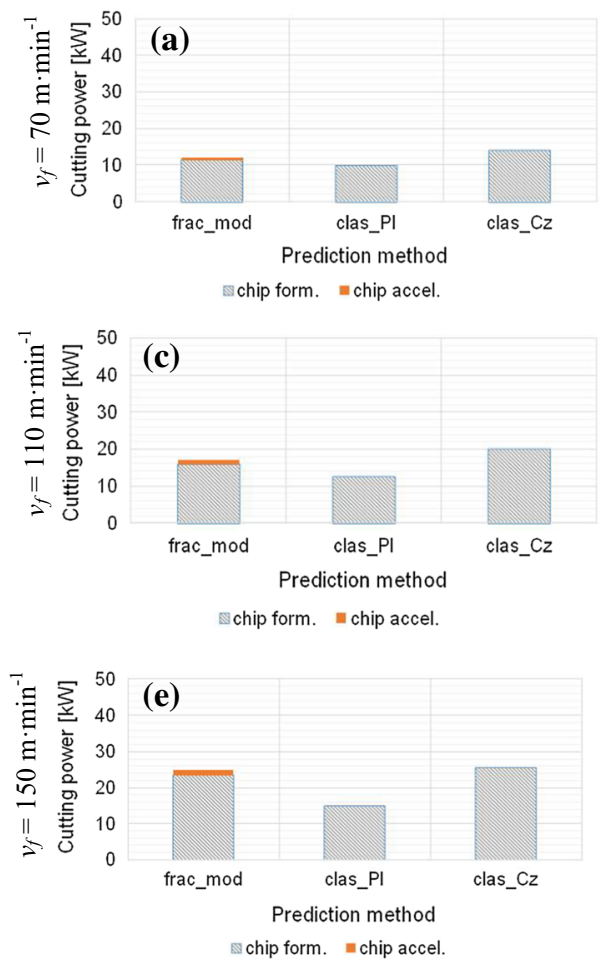

Beech
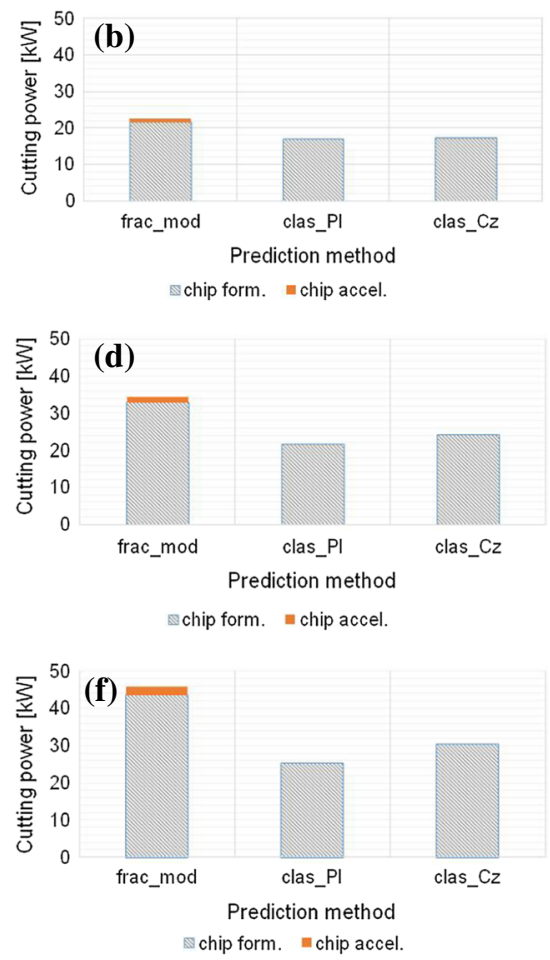

Fig. 8 Predictions of the total cutting power as a function of wood species and feed speed $\left(v_{\mathrm{f}}=70 \mathrm{~m} \mathrm{~min}^{-1}, v_{\mathrm{f}}=110 \mathrm{~m} \mathrm{~min}^{-1}\right.$ and $\left.v_{\mathrm{f}}=150 \mathrm{~m} \mathrm{~min}^{-1}\right)$, where a, c, e pine wood, b, d, f beech wood

- in case of pine sawing with a feed speed equal to $70 \mathrm{~m} \mathrm{~min}^{-1}$, the obtained value in the model CLAS_PL was smaller by $17.9 \%$; nevertheless, the cutting power in the CLAS_CZ model was overestimated with the difference equal to $16.4 \%$;

- in case of pine sawing with feed speed equal to $110 \mathrm{~m} \mathrm{~min}^{-1}$, the obtained value in the model CLAS_PL was smaller by $26.1 \%$. However, the cutting power in the CLAS_CZ model was again overestimated with the difference equal to $17.4 \%$;

- in case of pine sawing with feed speed equal to $150 \mathrm{~m} \mathrm{~min}^{-1}$, the obtained value in the model CLAS_PL was smaller by about $40.1 \%$. On the other hand, the cutting power in the CLAS_CZ model was slightly larger with the difference equal to only $2.9 \%$;

- in case of beech wood sawing with feed speed equal to $70 \mathrm{~m} \mathrm{~min}^{-1}$, the obtained value in the model CLAS_PL was $24.4 \%$ smaller. Nonetheless, the cutting power in the CLAS_CZ model was also smaller with the difference equal to only $23.7 \%$, almost the same as in the Polish case;

- in case of beech wood sawing with feed speed equal to $110 \mathrm{~m} \mathrm{~min}^{-1}$, the obtained value in the model CLAS_PL was 37.3\% smaller. Nevertheless, the 
cutting power in the CLAS_CZ model was also smaller with the difference equal to $29.9 \%$;

- in case of beech wood sawing with feed speed equal to $150 \mathrm{~m} \mathrm{~min}^{-1}$, the obtained value in the model CLAS_PL was smaller by about $45 \%$. On the other hand, the cutting power in the CLAS_CZ model was smaller about $33 \%$.

The conducted analyses have shown that almost in each case of forecasting the cutting power with the use of the classical models, the obtained values are underestimated, except for the results from the CLAS_CZ model for pine wood, in which the obtained values are overestimated in the range of 2.9-17.4\%. The underestimation seems to be dangerous in industrial practice, because, as a matter of fact, tools could be extra loaded and simultaneously, sawing accuracy could be decreased. Hence, the FRAC_MOD cutting model could be recommended for forecasting changes in cutting power in case of dynamical analyses and even unsteady cases. Moreover, the FRAC_MOD model takes into account the wood species, which properties are represented by fracture toughness and shear yield stress, tool geometry, friction between chip and rake surface, and the provenance of wood. The latter is particularly important as proven in the papers by Chuchala et al. (2014) and Minagawa et al. (2018).

\section{Conclusion}

The carried out analyses allowed us to conclude that the FRAC_MOD cutting model allows a good estimation with a given reality error (as presented by Orlowski and Ochrymiuk 2017 and Orlowski et al. 2017), while CLAS_PL and CLAS_CZ models underestimate the reality on average by about $34 \%$. In sawmill practice, such effects of underestimation could lead to extra loaded tools and in consequence sawing accuracy could be decreased (snaking phenomenon is present). It should be emphasized that the FRAC_MOD model seems to be more reliable since values of shear yield stresses and fracture toughness were obtained empirically in the cutting tests, which have been recommended for the determination of the cut material properties as an alternative and effective way. Moreover, the proposed FRAC_MOD model could be included in a small class of sawing process models based on physical foundations and describing the most important physical phenomena occurring in the machining process, in contrast to empirical models that have been widely and sometimes uncritically used for a long time. In view of the contemporary challenges facing the wood industry, such as precision machining and energy saving in production processes, it is reasonable to design new models based on physical phenomena. Such models allow for a more thorough analysis of woodworking processes and thus a more reliable forecasting of power consumption.

Acknowledgements This work is dedicated in memory of Professor Anthony Atkins of Reading University (UK) (died in 2018), who was an acknowledged expert in the field of fracture of all sorts of materials, including biomaterials, and a pioneer of practical application of the contemporary fracture mechanics to cutting processes. 
Funding This research did not receive any specific grant from funding agencies in the public, commercial or not-for-profit sectors.

\section{Compliance with ethical standards}

Conflict of interest On behalf of all authors, the corresponding author states that there is no conflict of interest.

Open Access This article is licensed under a Creative Commons Attribution 4.0 International License, which permits use, sharing, adaptation, distribution and reproduction in any medium or format, as long as you give appropriate credit to the original author(s) and the source, provide a link to the Creative Commons licence, and indicate if changes were made. The images or other third party material in this article are included in the article's Creative Commons licence, unless indicated otherwise in a credit line to the material. If material is not included in the article's Creative Commons licence and your intended use is not permitted by statutory regulation or exceeds the permitted use, you will need to obtain permission directly from the copyright holder. To view a copy of this licence, visit http://creativecommons.org/licen ses/by/4.0/.

\section{References}

Altintas Y (2000) Modeling approaches and software for predicting the performance of milling operations at MAL-UBC. Mach Sci Technol 4(3):445-478

Ammar AA, Bouaziz Z, Aghal A (2009) Modelling and simulation of the cutting forces for 2.5D pockets machining. Adv Prod Eng Manag 4(4):163-176

Astakhov VP (2010) Chapter 2: Basic definitions and cutting tool geometry, single point cutting tools. In: Pham DT (ed) Geometry of single-point turning tools and drills. Fundamentals and practical applications. Springer series in advanced manufacturing. Springer, London, pp 54-101. https://doi. org/10.1007/978-1-84996-053-3

Atkins AG (2003) Modelling metal cutting using modern ductile fracture mechanics: quantitative explanations for some longstanding problems. Int J Mech Sci 45:373-396

Atkins AG (2005) Toughness and cutting: a new way of simultaneously determining ductile fracture toughness and strength. Eng Fract Mech 72:849-860

Atkins AG (2009) The science and engineering of cutting. The mechanics and process of separating, scratching and puncturing biomaterials, metals and non-metals. Butterworth-Heinemann is an imprint of Elsevier, Oxford

Atkins T (2018) The importance of toughness in manufacturing. J Mater Process Technol 261:280-294. https://doi.org/10.1016/j.jmatprotec.2018.04.042

Axelsson BOM, Lundberg ÅS, Grönlund A (1993) Studies of the main cutting force at and near a cutting edge. Holz Roh Werkst 51(1):43-48

Beer P (2002) Obróbka skrawaniem obwodowym drewna nowo opracowanymi narzędziami (In Polish: Wood peeling with new elaborated tools). Roczniki Akademii Rolniczej w Poznaniu, Rozprawy Naukowe, Zeszyt 330. Wydawnictwo Akademii Rolniczej im. Augusta Cieszkowskiego w Poznaniu, Poznań

Beer P, Sinn G, Gindl M, Tschegg S (2005) Work of fracture and of chips formation during linear cutting of particle-board. J Mater Process Technol 159:224-228. https://doi.org/10.1016/j.jmatprotec .2004.05.009

Beršadskij AL (1967) Rasčet režimov rezaniá drevesiny (in Russian: Resolution of modes of wood machining). Lesnaá promyšlennost', Moskva

Böllinghaus T, Byrne G, Cherpakov BI, Chlebus E, Cross CE, Denkena B, Dilthey U, Hatsuzawa T, Herfurth K, Herold H et al (2009) Machining processes (Part 7-3 of chapter: manufacturing engineering). In: Grote K-H, Antonsson KK (eds) Springer handbook of mechanical engineering. Springer, Würzburg, pp 609-656

Budak E (2006) Analytical models for high performance milling. Part I: cutting forces, structural deformations and tolerance integrity. Int J Mach Tools Manuf 46(12-13):1478-1488 
Chuchala D, Orlowski KA, Sandak A, Sandak J, Pauliny D, Barański J (2014) The effect of wood provenance and density on cutting forces while sawing Scots pine (Pinus sylvestris L.). BioResources 9(3):5349-5361. https://doi.org/10.15376/biores.9.3.5349-5361

Gere JM (2004) Mechanics of materials. Thomson Learning Inc. http://www.hljp.edu.cn/attachment /20120820084627006.pdf. Accessed 18 Dec 2018

Glass SV, Zelinka SL (2010) Moisture relations and physical properties of wood, chapter 4. In: Wood handbook-wood as an engineering material. [online] (Centennial Edition). General technical report FPL-GTR-190. U.S. Department of Agriculture, Forest Service, Forest Products Laboratory, Madison, WI. http://www.fpl.fs.fed.us/documnts/fplgtr/fpl_gtr190.pdf. Accessed 12 Feb 2020

Grzesik W (2017) Advanced machining processes of metallic materials. Theory, modelling, and applications, 2nd edn. Elsevier, Amsterdam. ISBN 978-0-444-63711-6

Grzesik W (2018) Podstawy skrawania materiałów konstrukcyjnych (in Polish: Fundamentals of construction materials cutting) Wydanie 3. Wydawnictwo Naukowo-Techniczne, Warszawa

Hlásková L, Orlowski KA, Kopecký Z, Jedinák M (2015) Sawing processes as a way of determining fracture toughness and shear yield stresses of wood. BioResources 10(3):5381-5394

Hlásková L, Orlowski K, Kopecký Z, Sviták M, Ochrymiuk T (2018) Fracture toughness and shear yield strength determination for two selected species of central European provenance. BioResources 13(3):6171-6186. https://doi.org/10.15376/biores.13.3.6171-6186

Hlásková L, Kopecký Z, Solař A, Potočka Z (2019) Cutting test as a source of fracture toughness and shear yield strength for axial-perpendicular model of wood cutting. Wood Fiber Sci 51(1):1-11. https://doi.org/10.22382/wfs-2019-006

Krenke T, Frybort S, Müller U (2017a) Determining cutting force parameters by applying a system function. Mach Sci Technol 21(3):436-451. https://doi.org/10.1080/10910344.2017.1284563

Krenke K, Frybort S, Müller U (2017b) Cutting force analysis of a linear cutting process of spruce. Wood Mater Sci Eng 13(5):279-285. https://doi.org/10.1080/17480272.2017.1324916

Kvietková M, Gaff M, Gašparík M, Kminiak R, Kriš A (2015) Effect of number of saw blade teeth on noise level and wear of blade edges during cutting of wood. BioResources 10(1):1657-1666

Lisičan J (1996) Teoria a technika spracovania dreva. (in Slovak: Theory and wood technology). Matcentrum, Zvolen. ISBN 80-967315-6-4

Manžos FM (1974) Derevorežuŝie stanki, (in Russian: Wood cutting machine tools). Izdatel'stvo Lesnaâ Promyšlennost', Moskva

Markopoulos AP (2013) Cutting mechanics and analytical modelling. In: Paulo Davim (ed) Finite element method in machining processes. Springer, London, pp 11-27. https://doi. org/10.1007/978-1-4471-4330-7_2

Melo LE, Silva JR, Napoli A, Lima JT, Trugilho PF, Nascimento DF (2016) Study of the physical properties of Corymbia citriodora wood for the prediction of specific cutting force. Sci For 44(111):701708. https://doi.org/10.18671/scifor.v44n111.16

Minagawa M, Matsuda Y, Fujiwara Y, Fujii Y (2018) Relationship between crack propagation and the stress intensity factor in cutting parallel to the grain of hinoki (Chamaecyparis obtusa). J Wood Sci 64:758-766. https://doi.org/10.1007/s10086-018-1760-6

Mohammadpanah A, Hutton SG (2016) Dynamics behavior of a guided spline spinning disk, subjected to conservative in-plane edge loads, analytical and experimental investigation. J Vib Acoust 138(4):041005-041005-11. https://doi.org/10.1115/1.4033456

Nascimento DF, Melo LE, Silva JR, Trugilho PF, Napoli A (2017) Effect of moisture content on specific cutting energy consumption in Corymbia citriodora and Eucalyptus urophylla woods. Sci For 45(113):221-227. https://doi.org/10.18671/scifor.v45n113.22

Nasir V, Cool J (2018) A review on wood machining: characterization, optimization, and monitoring of the sawing process. Wood Mater Sci Eng 15(1):1-16. https://doi.org/10.1080/17480272.2018.14654 65

Nasir V, Mohammadpanah A, Cool J (2018) The effect of rotation speed on the power consumption and cutting accuracy of guided circular saw: experimental measurement and analysis of saw critical and flutter speeds. Wood Mater Sci Eng. https://doi.org/10.1080/17480272.2018.1508167

Naylor A, Hackney P (2013) A review of wood machining literature with a special focus on sawing. BioResources 8(2):3122-3135

Naylor A, Hackney P, Perera N, Clahr E (2012) A predictive model for the cutting force in wood machining developed using mechanical properties. BioResources 7(3):2883-2894

Orlicz T (1988) Obróbka drewna narzędziami tnącymi. (in Polish: Wood processing with cutting tools). Skrypty SGGW-AR w Warszawie, Wydawnictwo SGGW-AR, Warszawa 
Orlowski KA (2010) The fundamentals of narrow-kerf sawing: the mechanics and quality of cutting. Publishing house of the Technical University in Zvolen, Technical University in Zvolen

Orlowski KA, Ochrymiuk T (2013) Revisiting the determination of cutting power while sawing of wood with circular saw blades by means of fracture mechanics. In: IWMS-21 Organizing Committee (eds) Proceedings of the 21st international wood machining seminar, August 4-7, 2011, Tsukuba, Japan. The Japan Wood Research Society, pp 46-55

Orlowski KA, Ochrymiuk T (2017) A newly-developed model for predicting cutting power during wood sawing with circular saw blades. Maderas Cienc Tecnol 19(2):149-162. https://doi.org/10.4067/ S0718-221X2017005000013

Orlowski KA, Walichnowski A (2013) Economic analysis of upper layer production of engineered floorings. Drewno 56(189):115-126. https://doi.org/10.12841/wood.1644-3985.022.08

Orlowski KA, Ochrymiuk T, Atkins A, Chuchala D (2013) Application of fracture mechanics for energetic effects predictions while wood sawing. Wood Sci Technol 47(5):949-963

Orlowski K, Ochrymiuk T, Atkins A (2014) An innovative approach to the forecasting of energetic effects while wood sawing. Drvna Ind 65(4):273-281. https://doi.org/10.5552/drind.2014.1341

Orlowski KA, Ochrymiuk T, Sandak J, Sandak A (2017) Estimation of fracture toughness and shear yield stress of orthotropic materials in cutting with rotating tools. Eng Fract Mech 178:433-444. https:// doi.org/10.1016/j.engfracmech.2017.02.023

Pantea RC (1999) Wood cutting system: modelling and process simulation. Mémoire présen té à la Faculté des études supérieures de l'université Laval pour l'obtention du grade de maître ès science (M.Sc.). Département de génie mécanique Faculté Des Sciences Et De Genie, Université Laval (National Library of Canada)

Pinkowski G, Krauss A, Sydor M (2016) The effect of spiral grain on energy requirement of plane milling of Scots pine (Pinus sylvestris L.) wood. BioResources 11(4):9302-9310. https://doi.org/10.15376/ biores.11.4.9302-9310

Porankiewicz B, Axelsson B, Grönlund A, Marklund B (2011) Main and normal cutting forces by machining wood of Pinus sylvestris. BioResources 6(4):3687-3713

Sandak J, Orłowski K, Ochrymiuk T, Sandak A, Riggio M (2017) Report for the Short Term Scientific Mission within COST Action FP1101: development of the in-field sensor for estimation of fracture toughness and shear strength by measuring cutting forces. Int Wood Prod J 8(1):34-38

Wang H, Chang L, Ye L, Williams JG (2015) On the toughness measurement for ductile polymers by orthogonal cutting. Eng Fract Mech 149:276-286. https://doi.org/10.1016/j.engfracmec h.2015.06.067

Wasielewski R, Orlowski KA, Szyszkowski S (2012) Economical wood sawing with circular saw blades of a new design. Drvna Ind 63(1):27-32. https://doi.org/10.5552/drind.2012.1121

Publisher's Note Springer Nature remains neutral with regard to jurisdictional claims in published maps and institutional affiliations.

\section{Affiliations}

\section{Kazimierz A. Orlowski ${ }^{1}$ (i) - Tomasz Ochrymiuk ${ }^{2}$ (I) - Ludka Hlaskova ${ }^{3}$. Daniel Chuchala ${ }^{1}\left[{ }^{\circledR} \cdot\right.$ Zdenek Kopecky $^{3}$}

Tomasz Ochrymiuk

tomasz.ochrymiuk@imp.gda.pl

Ludka Hlaskova

ludka.hlaskova@mendelu.cz

Daniel Chuchala

daniel.chuchala@pg.edu.pl

Zdenek Kopecky

kopecky@mendelu.cz 
1 Department of Manufacturing Engineering and Automation, Faculty of Mechanical Engineering, Gdansk University of Technology, Narutowicza 11/12, Gdańsk, Poland

2 Centre of Flow and Combustion, Institute of Fluid-Flow Machinery, Polish Academy of Sciences, Fiszera 14, Gdańsk, Poland

3 Faculty of Forestry and Wood Technology, Mendel University in Brno, Zemědělská 1/1665, 61300 Brno, Czech Republic 